\title{
$\beta$-Trefoil Protease Inhibitors Unique to Higher Fungi
}

\author{
Jerica Sabotič, ${ }^{1, \star}$ Miha Renko $^{2}$ and Janko Kos ${ }^{1,3}$ \\ ${ }^{1}$ Department of Biotechnology, Jožef Stefan Institute, Ljubljana, Slovenia \\ ${ }^{2}$ MRC Laboratory of Molecular Biology, Cambridge, United Kingdom \\ ${ }^{3}$ Faculty of Pharmacy, University of Ljubljana, Ljubljana, Slovenia \\ * Corresponding author: E-mail: jerica.sabotic@ijs.si; \\ Tel: +38614773754; Fax: +38614773594
}

Received: 05-14-2018

Dedicated to the memory of Prof. Dr. Igor Kregar

\begin{abstract}
The cysteine protease inhibitors, clitocypin and macrocypins, from higher fungi (mycocypins), together with the serine protease inhibitors highly specific for trypsin cospin and cnispin from higher fungi (mycospins), display several characteristics that distinguish them from protease inhibitors from other sources. Their high genetic heterogeneity affects their functionality and/or stability and results in numerous protein variants with slightly different inhibitory profiles that influence the type of protease inhibited and/or the strength of inhibition. They possess the $\beta$-trefoil fold that shows high plasticity in their utilization of the 11 diverse loops for the inhibition of various families of proteases through different mechanisms of inhibition. Their high versatility is also seen in their regulatory and defence functions and in their potential applications in biotechnology, crop protection and medicine.
\end{abstract}

Keywords: Protease inhibitor; regulation; defence; clitocypin; macrocypin; cospin

\section{Introduction}

Proteolytic enzymes, also termed proteases or peptidases, are degradative enzymes that catalyse the hydrolysis of peptide bonds. They are ubiquitous and essential for the survival of all organisms, since they enable nutrient acquisition, growth, proliferation and reproduction. Furthermore, they are critical for defence against pathogens and parasites. Since their activity is so essential, it needs to be tightly regulated and dysregulation often leads to disease. ${ }^{1-5}$ Because of their important roles in physiological and pathophysiological processes they are paramount targets and tools in the search for new strategies with applications in medicine, pharmaceutical industry and agriculture.

The regulation of proteolytic enzymes is also vital, because hydrolysis of peptide bonds is irreversible. Specific protease inhibitors play a very important role in their regulation. ${ }^{6-9}$ For this reason, we undertook a search for further protease inhibitors that could exhibit unique inhi- bitory specificity, provide new mechanisms of inhibition and offer multiple possibilities in medical and biotechnological applications.

We decided to utilize higher fungi or mushrooms as a new and promising source of protease inhibitors ${ }^{10}$ since very little was known at the time about the proteolytic systems in higher fungi. A first glimpse of the complexity of these systems was provided by an investigation of the proteolytic activity of mushrooms using gelatin zymography combined with selected protease inhibitors. The number and diversity of proteolytically active bands observed was unexpectedly high. These proteases were classified into different catalytic classes, a large proportion of them showing atypical properties. This indicated the great potential for finding novel protease inhibitors in the proteolytic systems of higher fungi. ${ }^{11}$

An overview is provided here of the protein protease inhibitors that we have identified in higher fungi, together with their unique features established by characterization at the genetic, molecular, structural and functional levels. 


\section{Protease Inhibitors from Higher Fungi}

Protease inhibitors are indispensable regulators of proteolytic enzymes and are present in all kingdoms of life. They can be classified according to their origin, inhibitory mechanism, structural similarity or their specificity. The last is most often used to group inhibitors according to those that inhibit a number of classes of peptidases, those that inhibit a single class of peptidases, those that inhibit one or more families of peptidases or just a single peptidase. ${ }^{6,12}$ The MEROPS database (https://www.ebi.ac.uk/merops/) provides the most extensive classification of protease inhibitors into families, based on sequence homology, and into clans, based on similarity of 3D structure. There are currently 79 families of protease inhibitors in the MEROPS database (release 12.0; April 2018). Of these, 24 include members of fungal origin and only seven include members from higher fungi, of which only four families (I9, I48, I66 and I85) include members that have been characterized at the protein level. ${ }^{13}$ Family 19 comprises subtilisin propeptide-like inhibitors isolated from oyster mushroom (Pleurotus ostreatus) ${ }^{14,15}$ and the other three are described in this review (Table 1).

Families I48 and I85 comprise mycocypins, the fungal cysteine protease inhibitors clitocypin ${ }^{16}$ (Clt, family I48) from the clouded agaric (Clitocybe nebularis), and macrocypin ${ }^{17}$ (Mcp, family I85) from parasol mushroom (Macrolepiota procera). Mycocypins are small proteins with molecular masses between $16.6 \mathrm{kDa}$ (clitocypin) and $19.0 \mathrm{kDa}$ (macrocypin 1) that have similar biochemical properties. They all exhibit isoelectric points around $\mathrm{pH}$ 4.8. An exceptional feature is their apparent resistance to high temperature and to extremes of $\mathrm{pH}$ that results from their ability to unfold reversibly. ${ }^{16-20}$ Furthermore, mycocypins are resistant to proteolytic digestion by the highly non-specific proteinase $\mathrm{K}$ although they do not inhibit its proteolytic activity. ${ }^{21}$

Family I66 comprises the trypsin-specific inhibitors mycospins: $\mathrm{cnispin}^{22}$ (Cnp) from Clitocybe nebularis and $\operatorname{cospin}^{23}$ (PIC) from Coprinopsis cinerea, as well as a representative from Lentinula edodes. ${ }^{24}$ These inhibitors are small proteins, the molecular mass of cnispin being 16.4 $\mathrm{kDa}$ and that of cospin $16.7 \mathrm{kDa}$ and both with a low isoelectric point around $\mathrm{pH} 5$. They are both stable at extreme $\mathrm{pH}$ and cospin is resistant to proteolytic digestion. ${ }^{21-23}$

\section{1. Genetic Heterogeneity}

Mycocypins are encoded by small families of genes whose members show sequence heterogeneity. Genes encoding clitocypin in the C. nebularis genome are composed of four exons and three short introns. Nucleotide substitutions are evenly distributed throughout the gene sequence. The diversity of amino acid substitutions however is mainly conservative and the isogene sequences for clitocypin share more than $90 \%$ identity at the level of the deduced protein sequence. ${ }^{25} \mathrm{~A}$ family of clitocypin encoding genes that show similar heterogeneity has also been detected in the $M$. procera genome. ${ }^{17}$

Genes encoding macrocypins in the $M$. procera genome are also composed of four exons and three introns. Their diversity is, however, much greater. The deduced amino acid sequences are divided into five groups with $75-86 \%$ sequence identity between groups and more than $90 \%$ sequence identity within groups. Some of the variable codons have been subject to positive evolutionary selecti-

Table 1. Overview of $\beta$-trefoil protease inhibitors from higher fungi.

\begin{tabular}{|c|c|c|c|c|c|c|}
\hline \multirow[b]{2}{*}{ Protease inhibitor } & \multicolumn{4}{|c|}{ Mycocypins } & \multicolumn{2}{|c|}{ Mycospins } \\
\hline & Clitocypin & Macrocypin 1 & Macrocypin 3 & Macrocypin 4 & Cnispin & Cospin \\
\hline Origin & $\begin{array}{l}\text { Clitocybe } \\
\text { nebularis }\end{array}$ & $\begin{array}{c}\text { Macrolepiota } \\
\text { procera }\end{array}$ & $\begin{array}{c}\text { Macrolepiota } \\
\text { procera }\end{array}$ & $\begin{array}{c}\text { Macrolepiota } \\
\text { procera }\end{array}$ & $\begin{array}{l}\text { Clitocybe } \\
\text { nebularis }\end{array}$ & $\begin{array}{c}\text { Coprinopsis } \\
\text { cinerea }\end{array}$ \\
\hline Abbreviation & Clt & Mcp1 & Mcp3 & Mcp4 & Cnp & PIC \\
\hline MEROPS family & I 48 & I85 & I85 & I85 & I66 & I66 \\
\hline Mass & $16582 \mathrm{Da}$ & $19062 \mathrm{Da}$ & $18900 \mathrm{Da}$ & $18639 \mathrm{Da}$ & $16407 \mathrm{Da}$ & $16713 \mathrm{Da}$ \\
\hline $\begin{array}{l}\text { Isoelectric } \\
\text { point }(\mathrm{pH})\end{array}$ & 4.8 & 4.8 & 4.8 & 5.1 & 5.2 & 4.9 \\
\hline PDB entry & 3H6R, 3H6S & $3 \mathrm{H} 6 \mathrm{Q}$ & l & l & I & $3 \mathrm{~N} 0 \mathrm{~K}, 3 \mathrm{VWC}$ \\
\hline $\begin{array}{l}\text { Protease family } \\
\text { inhibited }\end{array}$ & $\mathrm{C} 1 / \mathrm{C} 13$ & $\mathrm{C} 1 / \mathrm{C} 13$ & $\mathrm{C} 1 / \mathrm{C} 13$ & $\mathrm{C} 1 / \mathrm{S} 1$ & S1 & S1 \\
\hline $\begin{array}{l}\text { Inhibitory } \\
\text { loop } \\
\text { Resistant to }\end{array}$ & $\begin{array}{c}\beta 1-\beta 2 \text { and } \\
\beta 3-\beta 4 / \beta 5-\beta 6 \\
\text { high }\end{array}$ & $\begin{array}{c}\beta 1-\beta 2 \text { and } \\
\beta 3-\beta 4 / \beta 5-\beta 6 \\
\text { high }\end{array}$ & $\begin{array}{c}\beta 1-\beta 2 \text { and } \\
\beta 3-\beta 4 / \beta 5-\beta 6 \\
\text { high }\end{array}$ & $\begin{array}{c}\beta 1-\beta 2 \text { and } \\
\beta 3-\beta 4 / \beta 5-\beta 6\end{array}$ & $\beta 11-\beta 12$ & $\beta 2-\beta 3$ \\
\hline exposure to & $\begin{array}{l}\text { temperature } \\
\text { \& extreme } \mathrm{pH}\end{array}$ & $\begin{array}{l}\text { temperature } \\
\text { \& extreme } \mathrm{pH}\end{array}$ & $\begin{array}{l}\text { temperature } \\
\text { \& extreme } \mathrm{pH}\end{array}$ & alkaline $\mathrm{pH}$ & extreme $\mathrm{pH}$ & extreme $\mathrm{pH}$ \\
\hline $\begin{array}{l}\text { Resistant to } \\
\text { proteolytic digestion } \\
\text { by proteinase } \mathrm{K}\end{array}$ & yes & yes & yes & yes & no & yes \\
\hline
\end{tabular}


on, indicating their importance for the function of the protein. ${ }^{17}$ Gene sequences encoding macrocypins are also present in the C. nebularis genome, the degree of sequence identity to that of macrocypin 2 from $M$. procera being the highest. ${ }^{26}$

Deduced amino acid sequences of macrocypins and clitocypin show very low overall sequence identities of 17 to $21 \%$ (Table $2 \&$ Figure 1). Furthermore, macrocypin sequences contain sulphur containing amino acids, a cysteine residue being present in most macrocypin sequences and several histidine and methionine residues are present in all macrocypins while they are absent in clitocypin sequences. On the other hand, the deduced amino acid sequences of both clitocypin and macrocypin contain high contents of proline and tyrosine but low contents of leucines. ${ }^{16,17,25}$

The low sequence identity between different families of mycocypins hinders the search for their homologs in other fungal genomes. Indeed, BLASTP analysis, using clitocypin sequence, across 145 fungal genomes revealed similar protein encoding genes in only four, namely Botryobasidium botryosum (10 genes), Rhizoctonia solani (4 genes), Laccaria amethystina (13 genes) and Laccaria bicolor (10 genes), all members of the class Agaricomycetes. ${ }^{27}$ These genomes include small families of clitocypin analog genes (indicated in brackets) that show low sequence identity between organisms. Given this low sequence identity, it is probable that mycocypins are much more widespread in higher fungi.

The complex regulation of expression of mycocypins at different levels is indicated by the different promoter sequences as well as by differences in 5'UTR, 3'UTR and intron sequences and in their lengths. This was confirmed by the distinct expression levels of clitocypin and macrocypin in both their origin mushrooms and in the model species $C$. cinerea. ${ }^{17,25,26}$

The expression of clitocypin appeared to be uniform at the protein level in both C. nebularis and M. procera fruiting bodies. The expression pattern guided by the clitocypin promoter in the model species was very similar to that of the constitutive promoter gpdII of glyceraldehyde3-phosphate dehydrogenase from Agaricus bisporus. Some differences indicating regulatory complexity are seen in the different levels of clitocypin mRNA expression in different parts of fruiting bodies and by variation of expression in mycelium. ${ }^{17,25,26}$

The complex expression pattern of macrocypin genes reflects and enhances the diversity of their gene sequences. They show tissue specific expression patterns at the promoter, mRNA and protein levels that differ for different macrocypin genes. ${ }^{26}$

In addition to developmental regulation of mycocypins, environmental factors have influenced their expression, as indicated by the clitocypin genes in L. bicolor mycelium, whose expression was upregulated specifically in the presence of an antagonistic soil bacterium, Collimonas fungivorans. ${ }^{28}$

Mycospins are encoded by very small gene families, as indicated by the sequence diversity in natural isolates of cnispin from C. nebularis fruiting bodies and confirmed in the $C$. cinerea genome for cospin, where four isogenes were found. Cnispin genes are composed of four exons and three short introns. The sequence identity between the deduced amino acid sequences of cnispin and cospin is 26 to $30 \%$ (Table 2 \& Figure 2). ${ }^{22,23}$

Despite the low sequence identity among mycospins, several homologous sequences have been found in different species. For example, a four-gene family was identified in L. bicolor with 17 to $30 \%$ amino acid sequence identity to that of cospin. ${ }^{23}$ Furthermore, BLASTP analyses across 145 fungal genomes, using cospin sequence, revealed similar protein encoding genes in 21 basidiomycete species from class Agaricomycetes and also in two ascomycetes. Either one gene or small gene families, ranging from 2 to 12 genes, were identified. ${ }^{27}$ Furthermore, mycospins were identified and characterized at the protein and functional levels in three additional basidiomycete species: Armillaria mellea, Macrolepiota procera and Amanita phalloides. ${ }^{29}$ Mycospins appear to be more widely present in fungi than mycocypins, although this could also be the consequence of more favourable search parameters arising from the higher sequence similarity among mycospins.

Table 2. A sequence identity matrix of mycocypin and mycospin deduced from amino acid sequences. The percent sequence identity is given for each pair. ID. identical.

\begin{tabular}{|c|c|c|c|c|c|c|c|c|c|}
\hline & Mcp1 & Mcp2 & Mcp3 & Mcp4 & Mcp5 & Clt-Kras & Clt-Vrh & PIC & Cnp \\
\hline Mcp1 & ID & 82.8 & 78.6 & 79.8 & 76.3 & 17.4 & 18.0 & 10.7 & 10.9 \\
\hline Mcp2 & & ID & 80.2 & 85.0 & 79.6 & 19.4 & 19.4 & 10.8 & 12.2 \\
\hline Mcp3 & & & ID & 80.8 & 78.4 & 21.1 & 21.7 & 10.8 & 11.6 \\
\hline Mcp4 & & & & ID & 82.0 & 18.2 & 18.8 & 10.8 & 13.9 \\
\hline Mcp5 & & & & & ID & 18.9 & 18.9 & 10.2 & 11.6 \\
\hline Clt-Kras & & & & & & ID & 91.4 & 12.6 & 13.9 \\
\hline Clt-Vrh & & & & & & & ID & 13.2 & 15.1 \\
\hline PIC & & & & & & & & ID & 27.0 \\
\hline Cnp & & & & & & & & & ID \\
\hline
\end{tabular}


Cnispin and cospin are expressed in vegetative mycelium and in fruiting bodies and are not secreted. Much (approximately 700 fold) higher expression in fruiting bodies than in mycelium has been determined for cospin. ${ }^{22,23}$

\section{2. Inhibitory Specificity}

Mycocypins inhibit cysteine proteases of plant and animal origins but the strength of inhibition against different proteases differs between members of clitocypin and macrocypin families (Table 3). They are all strong inhibitors of papain-like proteases (family $\mathrm{C} 1$ ), with equilibrium constants for inhibition $\left(K_{\mathrm{i}}\right)$ ranging from picomolar to micromolar for various cysteine cathepsins and papain. Cathepsins with endopeptidase activities are strongly inhibited while cathepsins $\mathrm{B}$ and $\mathrm{H}$, that exhibit both endopeptidase and exopeptidase activity, are not inhibited by clitocypins and only very weakly by macrocypins. They also inhibit legumain/asparaginyl peptidase with $K_{\mathrm{i}}$ in the nanomolar range, albeit involving a different inhibitory active site (Figure $1 \& 3$ ). The latter is, in some macrocypins, changed and trypsin is inhibited instead of legumain. The sequence heterogeneity in the clitocypin gene family has no influence on the inhibitory activity while the greater sequence heterogeneity in macrocypin sequences is reflected in their inhibitory profiles (Table 3). ${ }^{17,20,22,23,30}$

Mycospins are strong and highly specific inhibitors of trypsin with values of $K_{\mathrm{i}}$ in the picomolar range for cospin and in the nanomolar range for cnispin. Both are also weak inhibitors of chymotrypsin with $K_{\mathrm{i}}$ in the micromolar range. Other serine proteases are very weakly or not at all inhibited (Table 3). ${ }^{22,23}$

Natural isolates of clitocypin and macrocypin display inhibitory profiles that differ slightly when (Table 4) compared with those of recombinant variants. This is the effect of the mixture of isoforms in the natural sample isolated from mushrooms growing in the wild. ${ }^{16,17,20,25}$ Despite their sequence heterogeneity, natural isolates of cnispin, CnSPIs, display the same inhibitory profile as cnispin and are very strong inhibitors of trypsin, while inhibition of chymotrypsin is about 40 times weaker and elastase and thrombin are not inhibited at all. ${ }^{22}$

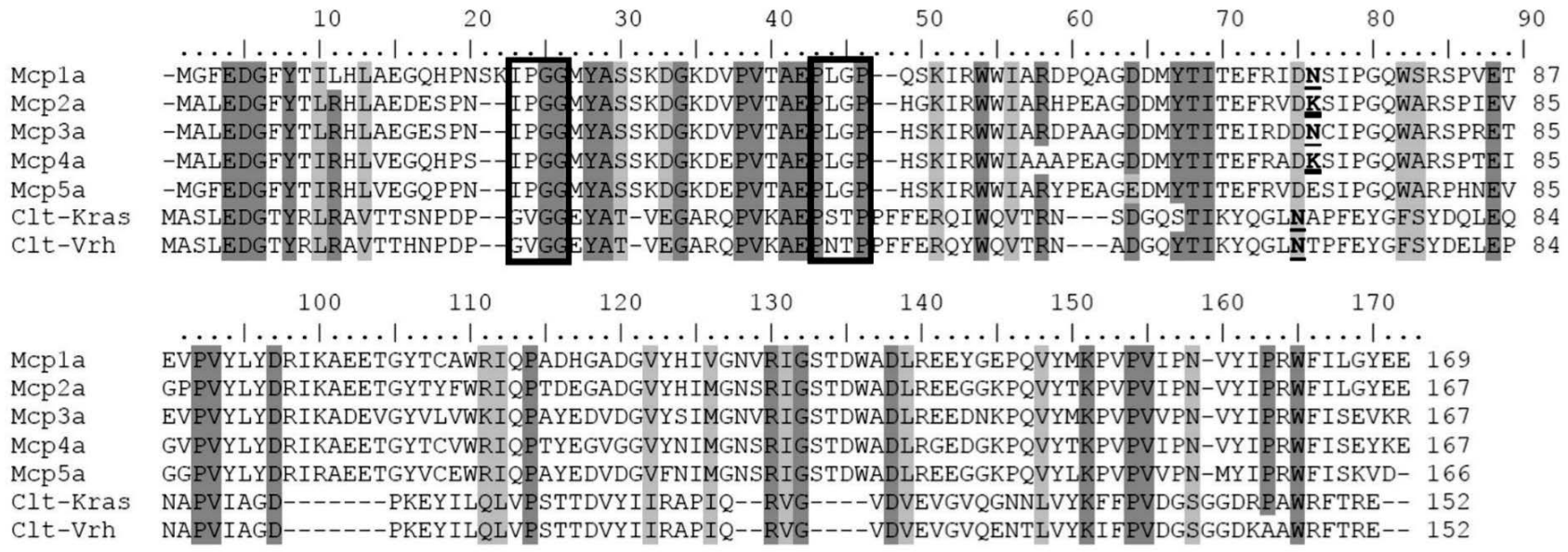

Figure 1. Alignment of mycocypin deduced amino acid sequences. Identical residues are highlighted in dark grey and similar residues in light grey. Amino acid sequences of macrocypins (Mcp) and clitocypins (Clt) were aligned with the BLOSUM62 matrix. Residues forming inhibitory loops that inhibit papain-like proteases are boxed. P1 residues, crucial for the inhibition of legumain or trypsin, are underlined and shown in bold. (Mcp macrocypin, Clt-Kras and Clt-Vrh are native sequences of clitocypin isolated from fruiting bodies collected in the two widely separated regions, Kras and Vrh in Slovenia.)

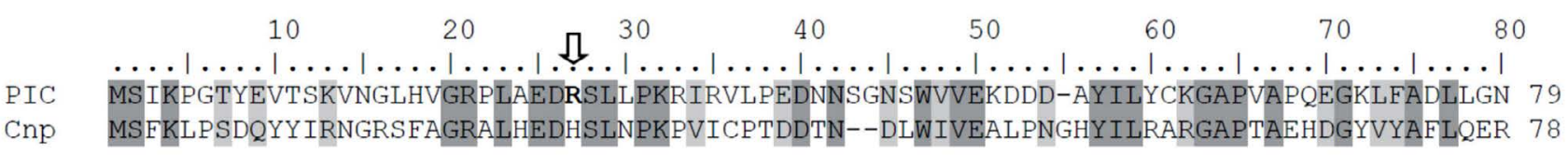

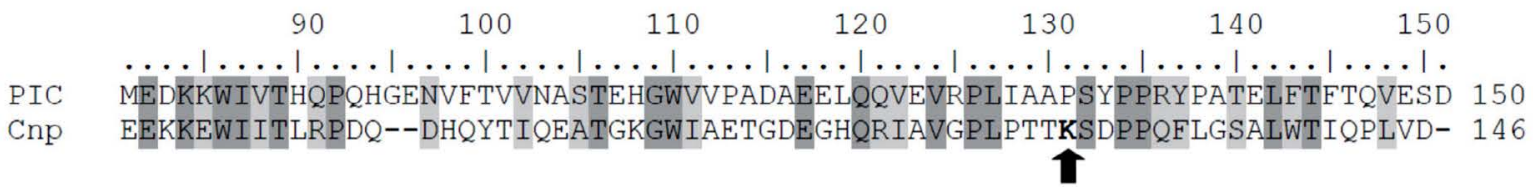

Figure 2. Alignment of deduced amino acid sequences of mycospins. Identical residues are highlighted in dark grey and similar residues in light grey. Amino acid sequences of cnispin (Cnp) and cospin (PIC) are aligned using the BLOSUM62 matrix. The arrows indicate the trypsin reactive P1 residue in cospin (white) and in cnispin (black). 
Table 3. Kinetic constants for the interaction of mycocypins and mycospins with various proteases. ${ }^{17,20,22,23,30}$ Standard deviations are given where appropriate. rClt, recombinant clitocypin; rMcp1, recombinant macrocypin 1; rMcp3, recombinant macrocypin 3; rMcp4 recombinant macrocypin 4; Cnp, recombinant cnispin; PIC, recombinant cospin; n.i., no inhibition; ND, not determined.

\begin{tabular}{|c|c|c|c|c|c|c|c|}
\hline \multirow{2}{*}{ Protease } & \multirow{2}{*}{$\begin{array}{c}\text { Protease } \\
\text { family }\end{array}$} & \multicolumn{6}{|c|}{$\mathrm{K}_{\mathrm{i}}(\mathrm{nM})$} \\
\hline & & rClt & rMcp1 & rMcp3 & rMcp4 & Cnp & PIC \\
\hline Papain & $\mathrm{C} 1$ & $6.2 \pm 0.55$ & $0.95 \pm 0.33$ & $0.12 \pm 0.05$ & $0.19 \pm 0.01$ & n.i. & n.i. \\
\hline Cathepsin L & $\mathrm{C} 1$ & $0.02 \pm 0.001$ & $0.64 \pm 0.22$ & $0.31 \pm 0.06$ & $2.76 \pm 0.92$ & ND & $\mathrm{ND}$ \\
\hline Cathepsin V & $\mathrm{C} 1$ & $0.08 \pm 0.03$ & $0.69 \pm 0.06$ & $0.45 \pm 0.01$ & $1.44 \pm 0.11$ & ND & ND \\
\hline Cathepsin S & $\mathrm{C} 1$ & $2.2 \pm 0.3$ & $23.1 \pm 1.2$ & $5.1 \pm 0.5$ & $6.3 \pm 0.6$ & ND & ND \\
\hline Cathepsin $\mathrm{K}$ & $\mathrm{C} 1$ & $0.03 \pm 0.002$ & $170 \pm 20$ & $17.5 \pm 1.2$ & $21.8 \pm 5.2$ & ND & ND \\
\hline Cathepsin B & $\mathrm{C} 1$ & $>1000$ & $490 \pm 18$ & $>1000$ & $125 \pm 10$ & ND & ND \\
\hline Cathepsin H & $\mathrm{C} 1$ & n.i. & $100 \pm 10$ & $24 \pm 5$ & $32 \pm 6$ & ND & ND \\
\hline Legumain & $\mathrm{C} 13$ & $21.5 \pm 2.81$ & $3.38 \pm 1.44$ & $9.17 \pm 1.09$ & $>1000$ & n.i. & n.i. \\
\hline Caspase 3, 6, 9 & $\mathrm{C} 14$ & n.i. & ND & ND & ND & ND & ND \\
\hline Trypsin & S1 & n.i. & n.i. & n.i. & $160 \pm 14$ & $3.10 \pm 0.66$ & $0.022 \pm 0.002$ \\
\hline Chymotrypsin & $\mathrm{S} 1$ & ND & ND & ND & ND & $120 \pm 20$ & $116 \pm 8$ \\
\hline Kallikrein & $\mathrm{S} 1$ & ND & ND & ND & ND & $>1000$ & $>1000$ \\
\hline Thrombin & $\mathrm{S} 1$ & ND & $\mathrm{ND}$ & ND & ND & n.i. & n.i. \\
\hline Subtilisin & S8 & ND & $\mathrm{ND}$ & ND & ND & $>1000$ & $>1000$ \\
\hline Pepsin & A1 & n.i. & n.i. & n.i. & n.i. & n.i. & n.i. \\
\hline
\end{tabular}

Table 4. Inhibition of various proteases by natural mycocypins. The kinetic data are as reported. ${ }^{17}$ Standard deviations are given where appropriate. nMcp, natural macrocypin; nClt, natural clitocypin; n.i., no inhibition.

\begin{tabular}{lccc}
\hline Enzyme & $\begin{array}{c}\text { Protease } \\
\text { family }\end{array}$ & nClt & nMcp \\
\hline Papain & $\mathrm{C} 1$ & $2.5 \pm 0.94$ & $5.04 \pm 0.98$ \\
Cathepsin L & $\mathrm{C} 1$ & $0.03 \pm 0.002$ & $3.81 \pm 1.66$ \\
Cathepsin V & $\mathrm{C} 1$ & $0.14 \pm 0.01$ & $12.6 \pm 3.77$ \\
Cathepsin S & $\mathrm{C} 1$ & $3.2 \pm 0.3$ & $47.1 \pm 3.1$ \\
Cathepsin K & $\mathrm{C} 1$ & $0.02 \pm 0.005$ & $4.5 \pm 0.5$ \\
Cathepsin B & $\mathrm{C} 1$ & $>1000$ & $515 \pm 36$ \\
Cathepsin H & $\mathrm{C} 1$ & n.i. & $370 \pm 11$ \\
Legumain & $\mathrm{C} 13$ & $7.1 \pm 1.12$ & $110 \pm 23$ \\
Trypsin & $\mathrm{S} 1$ & n.i. & n.i. \\
Pepsin & $\mathrm{A} 1$ & n.i. & n.i. \\
\hline
\end{tabular}

\section{3. Structural Plasticity}

Mycocypins and mycospins both possess a $\beta$-trefoil fold, ${ }^{23,31}$ thus classifying them to clan IC in the MEROPS classification, together with Kunitz serine protease inhibitors from plants (family I3). ${ }^{13}$

The $\beta$-trefoil fold consists of a $\beta$-barrel composed of three pairs of antiparallel $\beta$-strands. An additional three pairs of $\beta$-strands cover the $\beta$-barrel. The strands are connected by loops of different shapes and compositions (Figure 3). The large surface area of the loops, that accounts for approximately $70 \%$ of the protein's total solvent accessible area, enables these proteins to interact with many different binding partners, including proteins, carbohydrates and DNA. .3,31,32 $^{2}$

For the inhibition of papain-like proteases, mycocypins utilize two loops $(\beta 1-\beta 2$ and $\beta 3-\beta 4)$ that bind to either side of the active site cleft with several hydrogen bonds, occluding the catalytic cysteine. The binding is associated with a glycine-glycine peptide-bond flip (Gly$24-G l y 25$ in clitocypin) that occurs before or concurrently with inhibitor docking. ${ }^{31}$ The mode of cysteine protease inhibition, as revealed by the cathepsin V - clitocypin complex, is unique in utilizing two loops to achieve inhibition, while other known modes of inhibition by cysteine protease inhibitors, like those of cystatins and thyropins, utilize three loops to achieve active site occlusion. ${ }^{31,32}$

Inhibition of asparaginyl peptidase/legumain by mycocypins is achieved via a second inhibitory active site in the $\beta 5-\beta 6$ loop. Site-directed mutagenesis has confirmed that residues Asn72 in macrocypins and Asn69 in clitocypin mediate inhibition of asparaginyl peptidase. ${ }^{31}$ Furthermore, the same inhibitory active site mediates the inhibition of trypsin when Asn replaces Lys or Arg in different macrocypins but not in clitocypin. ${ }^{31}$ The inhibitory mechanism of the cysteine protease asparaginyl peptidase (family C13) and of the serine protease trypsin (family S1) appears to involve a similar substrate-like binding inhibition. ${ }^{32}$

Cospin and cnispin are classic canonical inhibitors that bind to the active site in a substrate-like manner and form a tight and stable complex with trypsin. The trypsin-cospin complex is stable for weeks at $37{ }^{\circ} \mathrm{C}$ while the trypsin-cnispin complex is degraded within $24 \mathrm{~h}$. This is also reflected in the stronger inhibition of trypsin by cospin as opposed to that by cnispin (Table 3 ). Inhibition of trypsin by mycospins is achieved through the different inhibitory reactive sites in cospin and cnispin. The reactive site residue P1 of cospin is Arg27 in the $\beta 2-\beta 3$ loop, while Lys127 in the $\beta 11-\beta 12$ loop of cnispin fulfils the same role (Figure $2 \& 3$ ). ${ }^{23,30}$ Inhibitory activity can be mediated by 

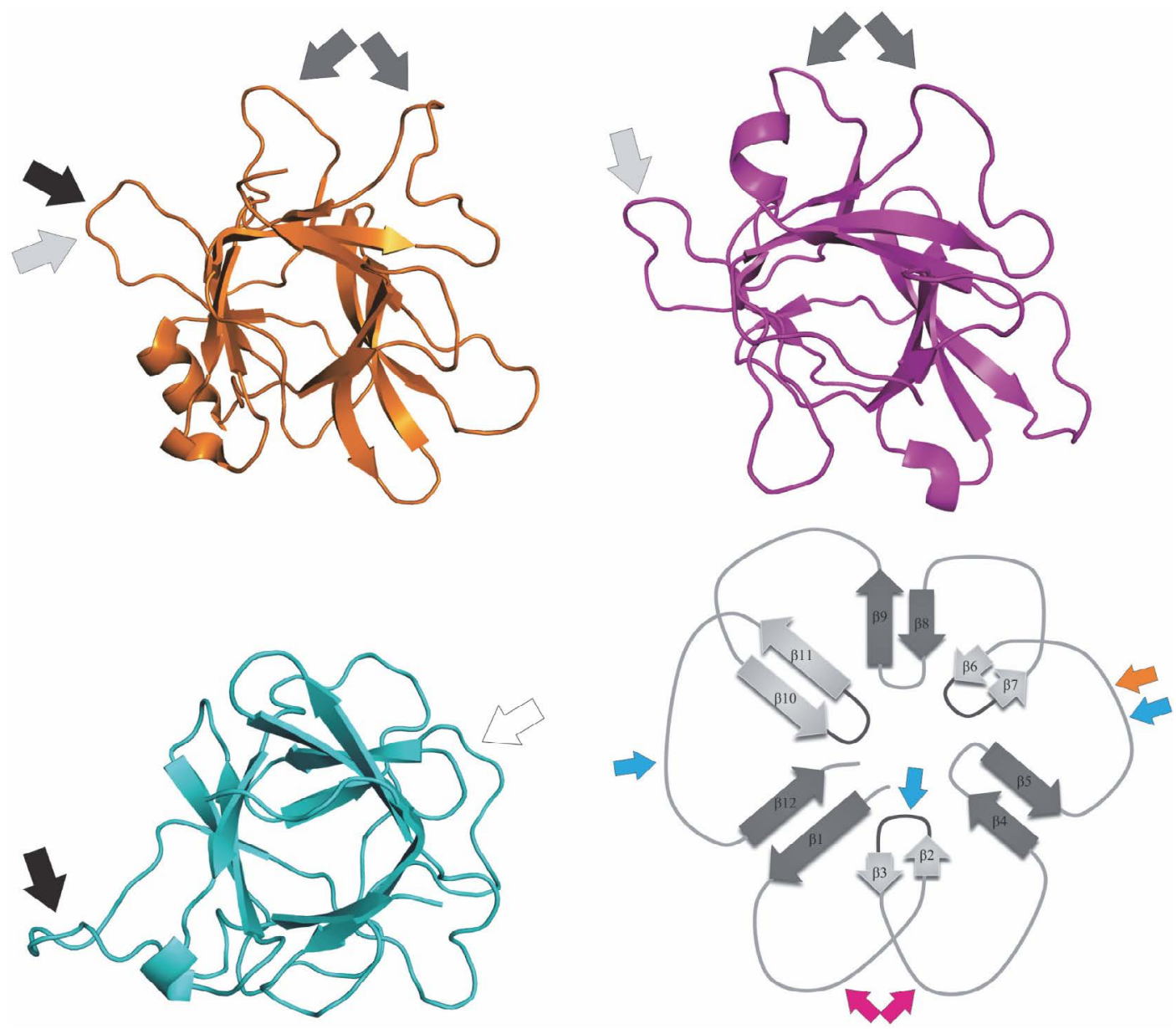

Figure 3. Structures of fungal cysteine protease inhibitors. Ribbon diagrams of the cysteine protease inhibitors macrocypin 1 (PDB code $3 \mathrm{H} 6 \mathrm{Q}$ ) in orange and clitocypin (PDB code 3H6S) in magenta are shown next to that of the serine protease inhibitor cospin (PDB code 3N0K9) in cyan. Loops with the following inhibitory reactive sites are marked with arrows: light grey arrows indicate asparaginyl protease/legumain inhibition, dark grey arrows indicate papain-like protease inhibition while white and black arrows indicate trypsin inhibition. A schematic representation of the $\beta$-trefoil fold loops involved in protease inhibition is shown bottom right. The protease family inhibited by individual loops of the $\beta$-trefoil fold in these fungal inhibitors is indicated by coloured arrows as follows: the asparaginyl protease/legumain with orange, papain-like proteases with magenta and trypsin with cyan.

both $\beta 2-\beta 3$ and $\beta 11-\beta 12$ loops in the two inhibitors; engineering of various $\mathrm{P} 1$ residues in the aforementioned loops yielded a strong or weak trypsin inhibitor, a chymotrypsin-specific inhibitor, a double headed trypsin inhibitor or a double-headed trypsin and chymotrypsin inhibitor. Other serine proteases are only weakly or not at all inhibited. Cysteine and aspartic proteases were not inhibited and asparaginyl peptidase/legumain inhibition was not achieved by introducing Asn as the $\mathrm{P} 1$ residue. ${ }^{30}$

\section{4. Functional Variability}

The proposed function of mycocypins and mycospins is to regulate both the endogenous proteolytic system and the defence against predators and pathogens. Mycocypins and mycospins are cytoplasmic proteins that are not secreted. In addition to the absence, in all the identified genes, of a signal sequence for the classical secretion and to the low number of cysteine residues and lack of glycosylation in natural samples, no secretion of cnispin and clitocypin has been detected from cultivated mycelium. $22,23,25$

An obvious biological role for protease inhibitors is the regulation of the endogenous proteolytic system. Activity of several cysteine proteases from fruiting bodies of different basidiomycetes is inhibited by clitocypin. ${ }^{11}$ Similarly, cnispin and cospin inhibit the activity of various serine proteases from their origin species as well as from other basidiomycetes. ${ }^{11,22,23}$ Regulation of the complex developmental and temporal expression of both mycocypins and mycospins indicates potentially different biological roles for different inhibitors. ${ }^{22,6}$

Another possible role for protease inhibitors, that is indirectly but strongly supported, is in defence against various antagonists. The strong toxicity of cnispin and cospin against Drosophila melanogaster larvae, their cytoplasmic localization and the higher expression in fruiting bodies 
compared to that in mycelium indicates their role in the defence of the spore-bearing fruiting body against dipteran larvae that hatch and feed on fruiting bodies. ${ }^{22,23}$ Protection of reproductive tissues from pests and diseases has also been suggested as a defensive role of mycocypins. Thus, cysteine proteases are predominant digestive proteases in many insects and slugs and could be targeted, like trypsin-like digestive proteases in dipteran insects are by mycospins. Furthermore, cysteine proteases are important virulence factors of different pathogenic bacteria, parasites and mycoviruses. These could be targeted by different mycocypins, as indicated by their different expression profiles. Clitocypin, which is constitutively expressed in large amounts in fruiting bodies, represents one line of defence, while the specific pattern of expression localized to the outer layer of the developing fruiting body of some macrocypins constitutes another defence strategy for protection against external attacks by predators or pathogens. The inducible expression of clitocypin analogs in L. bicolor when challenged by an antagonistic soil bacterium supports their role in defence. A defensive role is further supported by the high thermal and $\mathrm{pH}$ stability and the resistance to proteolytic degradation of these proteins, as well as by their high sequence diversity and versatile inhibitory profile. . $^{7,22,23,25,26,28}$

Another layer of regulation of the $\beta$-trefoil fungal protease inhibitors mycocypins and mycospins, is indicated by their interaction in vitro with $\beta$-trefoil lectins $\mathrm{MpL}$ and CNL from the same species, which are also expressed intracellularly and involved in fruiting body defence. ${ }^{21,27,33-36}$

\section{5. Diverse Applications}

Based on their unique characteristics indicating their function in defence, as described in the previous section, mycocypins have been evaluated for their potential in protecting plants against herbivores. A major pest, Colorado potato beetle (Leptinotarsa decemlineata), that utilizes cysteine proteases for protein digestion, has been used as a model. Clitocypin and macrocypins were shown to exhibit adverse effects on Colorado potato beetle larvae, both when expressed as proteins in potato leaves and when recombinant proteins produced in a bacterial expression system were added to the diet. Clitocypin and macrocypins reduced the weight gain of larvae and delayed their development. The effect was linked to inhibition of the special adaptive cysteine proteases, intestains, in larval guts. Moreover, dietary mycocypins did not induce the expression of known adaptation-related genes of digestive enzymes in guts of Colorado potato beetle larvae, as was the case with all other dietary inhibitors from other sources. ${ }^{37,38}$

The potential of mycocypins and mycospins in biotechnological applications has been confirmed by their use as ligands in affinity chromatography for isolating proteases from various sources. Trypsin was isolated from a complex, partially purified, trypsin sample using cnispin-affi- nity chromatography. Active cysteine proteases of families $\mathrm{C} 1$ (papain-like) and C13 (legumain/asparaginyl protease) have been isolated from plant and animal sources using macrocypin affinity chromatography. Their superior characteristics in terms of stability to $\mathrm{pH}$ and temperature make them ideal candidates for use as affinity chromatography ligands. They withstand the harsh conditions during immobilization procedures. For example, following $24 \mathrm{~h}$ incubation at neutral $\mathrm{pH}$ and $45^{\circ} \mathrm{C}$ for covalent binding to a monolithic disk, the unoccupied groups are inactivated by incubation for $1 \mathrm{~h}$ in $0.5 \mathrm{M} \mathrm{H}_{2} \mathrm{SO}_{4}$ at $50{ }^{\circ} \mathrm{C}$ and macrocypins then retain their inhibitory activity through several elution cycles of extreme $\mathrm{pH}$ changes. ${ }^{39}$

The distinct inhibitory profiles of mycocypins and the highly specific inhibitory profile of mycospins makes them valuable tools in medical research, since many cell processes depend on appropriately regulated proteolytic activity. Protease inhibitors are being studied as promising therapeutic drugs for many types of disease by targeting a variety of deregulated proteases, including those involved in cancer and autoimmune, neurodegenerative, inflammatory, and cardiovascular diseases; secreted bacterial, fungal, and parasite proteases; and viral polyprotein processing proteases. ${ }^{7,40}$

\section{Conclusions and Future Perspectives}

Protein protease inhibitors from a number of higher fungi exhibit a variety of unique characteristics when compared to similar protease inhibitors from plant, animal or microbial sources. Distinct inhibitory specificity profiles, coupled with structural plasticity of the $\beta$-trefoil fold, afford these inhibitors their diverse functions. Further, their noteworthy stability enables wide-ranging application of mycocypins and mycospins. The uniqueness of these protease inhibitors lies in the combination of the mentioned exceptional features in one protein family promoted by lack of homologues outside of the fungal kingdom.

The protease inhibitors from higher fungi described here just scratch the surface of the immense potential of the fungal proteolytic defence system hidden in forests in Slovenia and in forests worldwide.

In addition to the cysteine protease inhibitors represented by mycocypins and the serine protease inhibitors represented by mycospins, there are most probably protease inhibitors waiting to be identified from higher fungi, possibly with the $\beta$-trefoil fold, that inhibit other catalytic classes of proteases, including aspartic and metallo-proteases. Another direction for research, involving the $\beta$-trefoil fold proteins with other functionalities such as carbohydrate binding, lies via the $\beta$-trefoil fold lectins that have been shown to be versatile and to support unique characteristics. It will be interesting to find more novel multifunctional proteins with both carbohydrate binding and 
inhibitory activities. Knowledge of the different functionalities evolved naturally in the $\beta$-trefoil scaffold will facilitate the engineering of customized multifunctional proteins.

\section{Acknowledgements}

We dedicate this paper to prof. Igor Kregar, who was the leader of our group for many years and initiated studies on plant and fungal biochemistry and molecular biology. We are grateful to dr. Jože Brzin who initiated the research on protease inhibitors from mushrooms and guided our investigations until recently. We thank dr. Tatjana Popovič who meticulously determined their kinetics and passed on her knowledge brilliantly. We are indebted to dr. Marjetka Kidrič and prof. Roger H. Pain for numerous discussions and invaluable input. We would also like to acknowledge the many other researchers and students from the Jožef Stefan Institute, the National Institute of Biology, the ETH Zürich and University of Bristol who, over the years, have contributed pieces of the puzzle to the knowledge we now have on fungal protease inhibitors.

\section{1. Funding}

This work was supported by the Research Agency of the Republic of Slovenia Grant P4-0127 (to J.K.).

\section{References}

1. C. Lopez-Otin and J. S. Bond, J Biol Chem 2008, 283, 3043330437. DOI:10.1074/jbc.R800035200

2. M. B. Rao, A. M. Tanksale, M. S. Ghatge and V. V. Deshpande, Microbiol Mol Biol Rev 1998, 62, 597-635.

3. H. Maeda, Microbiol Immunol 1996, 40, 685-99. DOI:10.1111/j.1348-0421.1996.tb01129.x

4. A. Schaller, Planta 2004, 220, 183-97. DOI:10.1007/s00425-004-1407-2

5. I. Yike, Mycopathologia 2011, 171, 299-323. DOI:10.1007/s11046-010-9386-2

6. N. D. Rawlings, D. P. Tolle and A. J. Barrett, Biochem J 2004, 378, 705-16. DOI:10.1042/bj20031825

7. J. Sabotič and J. Kos, Appl Microbiol Biot 2012, 93, 1351-75. DOI:10.1007/s00253-011-3834-x

8. R. Sharma, in: R. Sharma (Ed.): Enzyme Inhibition and Bioapplications, InTech, 2012, pp. 3-36. DOI:10.5772/1963

9. N. D. Rawlings, M. Waller, A. J. Barrett and A. Bateman, Nucleic acids research 2014, 42, D503-9. DOI:10.1093/nar/gkt953

10. J. Erjavec, J. Kos, M. Ravnikar, T. Dreo and J. Sabotič, Trends Biotechnol 2012, 30, 259-73.

DOI:10.1016/j.tibtech.2012.01.004

11. J. Sabotič, T. Trček, T. Popovič and J. Brzin, J Biotechnol 2007, 128, 297-307. DOI:10.1016/j.jbiotec.2006.10.006

12. G. Salvesen and H. Nagase, in: R. J. Benyou and J. S. Bond
(Eds.): Proteolytic enzymes: A practical approach, IRL Press, Oxford, 1989, pp. 83-104.

13. N. D. Rawlings, A. J. Barrett, P. D. Thomas, X. Huang, A. Bateman and R. D. Finn, Nucleic Acids Res 2018, 46, D624-D632. DOI:10.1093/nar/gkx1134

14. N. Dohmae, K. Takio, Y. Tsumuraya and Y. Hashimoto, Arch Biochem Biophys 1995, 316, 498-506.

DOI:10.1006/abbi.1995.1066

15. S. Kojima, A. Iwahara and H. Yanai, FEBS Lett 2005, 579, 4430-6. DOI:10.1016/j.febslet.2005.06.083

16. J. Brzin, B. Rogelj, T. Popovič, B. Štrukelj and A. Ritonja, J. Biol. Chem. 2000, 275, 20104-9.

DOI:10.1074/jbc.M001392200

17. J. Sabotič, T. Popovič, V. Puizdar and J. Brzin, FEBS J 2009, 276, 4334-45. DOI:10.1111/j.1742-4658.2009.07138.x

18. M. Kidrič, H. Fabian, J. Brzin, T. Popovič and R. H. Pain, Biochem. Biophys. Res. Commun. 2002, 297, 962-7.

DOI:10.1016/S0006-291X(02)02328-8

19. K. Galeša, R. M. Thomas, M. Kidrič and R. H. Pain, Biochem Biophys Res Commun 2004, 324, 576-8.

DOI:10.1016/j.bbrc.2004.09.092

20. J. Sabotič, K. Galeša, T. Popovič, A. Leonardi and J. Brzin, Protein Expr Purif 2007, 53, 104-11. DOI:10.1016/j.pep.2006.11.015

21. S. Žurga, J. Pohleven, J. Kos and J. Sabotič, J Biochem 2015, 158, 83-90. DOI:10.1093/jb/mvv025

22. P. Avanzo, J. Sabotič, S. Anžlovar, T. Popovič, A. Leonardi, R. H. Pain, J. Kos and J. Brzin, Microbiology 2009, 155, 3971-81. DOI:10.1099/mic.0.032805-0

23. J. Sabotič, S. Bleuler-Martinez, M. Renko, P. Avanzo Caglič, S. Kallert, B. Štrukelj, D. Turk, M. Aebi, J. Kos and M. Künzler, J Biol Chem 2012, 287, 3898-907.

DOI:10.1074/jbc.M111.285304

24. S. Odani, K. Tominaga, S. Kondou, H. Hori, T. Koide, S. Hara, M. Isemura and S. Tsunasawa, Eur J Biochem 1999, 262, 915 -

23. DOI:10.1046/j.1432-1327.1999.00463.x

25. J. Sabotič, D. Gaser, B. Rogelj, K. Gruden, B. Štrukelj and J. Brzin, Biol Chem 2006, 387, 1559-66.

DOI:10.1515/BC.2006.194

26. J. Sabotič, S. Kilaru, M. Budič, M. B. Gašparič, K. Gruden, A. M. Bailey, G. D. Foster and J. Kos, Biochimie 2011, 93, 16851693. DOI:10.1016/j.biochi.2011.05.034

27. J. Sabotič, R. A. Ohm and M. Künzler, Appl Microbiol Biot 2015, submitted.

28. A. Deveau, M. Barret, A. G. Diedhiou, J. Leveau, W. de Boer, F. Martin, A. Sarniguet and P. Frey-Klett, Microbial ecology 2015, 69, 146-59. DOI:10.1007/s00248-014-0445-y

29. T. Lukanc, J. Brzin, J. Kos and J. Sabotič, Acta Biochim Pol 2017, 64, 21-24. DOI:10.18388/abp.2015_1187

30. P. Avanzo Caglič, M. Renko, D. Turk, J. Kos and J. Sabotič, Biochimica et Biophysica Acta 2014, 1844, 1749-56.

31. M. Renko, J. Sabotič, M. Mihelič, J. Brzin, J. Kos and D. Turk, J Biol Chem 2010, 285, 308-16.

DOI:10.1074/jbc.M109.043331

32. M. Renko, J. Sabotič and D. Turk, Biological chemistry 2012, 393, 1043-54. DOI:10.1515/hsz-2012-0159 
33. J. Pohleven, J. Brzin, L. Vrabec, A. Leonardi, A. Čokl, B. Štrukelj, J. Kos and J. Sabotič, Appl Microbiol Biotechnol 2011, 91, 1141-8. DOI:10.1007/s00253-011-3236-0

34. J. Pohleven, N. Obermajer, J. Sabotič, S. Anžlovar, K. Sepčić, J. Kos, B. Kralj, B. Štrukelj and J. Brzin, Biochim Biophys Acta 2009, 1790, 173-81.

35. J. Pohleven, M. Renko, S. Magister, D. F. Smith, M. Künzler, B. Štrukelj, D. Turk, J. Kos and J. Sabotič, J Biol Chem 2012, 287, 10602-12. DOI:10.1074/jbc.M111.317263

36. S. Žurga, J. Pohleven, M. Renko, S. Bleuler-Martinez, P. Sosnowski, D. Turk, M. Künzler, J. Kos and J. Sabotič, FEBS J 2014, 281, 3489-506. DOI:10.1111/febs. 12875
37. I. Šmid, K. Gruden, M. Buh Gašparič, K. Koruza, M. Petek, J. Pohleven, J. Brzin, J. Kos, J. Žel and J. Sabotič, J Agr Food Chem 2013, 61, 12499-509. DOI:10.1021/jf403615f

38. I. Šmid, A. Rotter, K. Gruden, J. Brzin, M. Buh Gašparič, J. Kos, J. Žel and J. Sabotič, Pestic Biochem Physiol 2015, 122, 59-66. DOI:10.1016/j.pestbp.2014.12.022

39. J. Sabotič, K. Koruza, B. Gabor, M. Peterka, M. Barut, J. Kos and J. Brzin, in: S. Magdeldin (Ed.): Affinity Chromatography, InTech, Rijeka, 2012, pp. 307-332.

40. J. Sabotič and J. Kos, in: J.-M. Mérillon and K. G. Ramawat (Eds.): Fungal Metabolites, Springer International Publishing, Switzerland, 2016.

\section{Povzetek}

Inhibitorji cisteinskih proteaz, klitocipin in makrocipini iz višjih gliv (mikocipini), skupaj s serinskima proteaznima inhibitorjema, ki sta zelo specifična za tripsin, kospin in knispin iz višjih gliv (mikospini), kažejo številne značilnosti, ki jih razlikujejo od inhibitorjev proteaz iz drugih virov. Visoka genetska raznolikost ima vpliv na funkcionalnost in / ali stabilnost proteinov in privede do številnih proteinskih variant z nekoliko različnimi inhibitornimi profili, ki vplivajo na vrsto tarčne proteaze in / ali moč inhibicije. Imajo $\beta$-triperesno zvitje, ki kaže visoko plastičnost pri uporabi 11 različnih zank za inhibicijo različnih družin proteaz z različnimi mehanizmi inhibicije. Njihova vsestranskost se kaže tudi v regulatorni in obrambni funkciji ter široki potencialni uporabi v biotehnologiji, kmetijstvu in medicini. 